\title{
Melatonin actions on ovaprim (synthetic GnRH and domperidone)-induced oocyte maturation in carp
}

\author{
Mahammed Moniruzzaman, Kazi Nurul Hasan and Saumen Kumar Maitra \\ Department of Zoology, Visva-Bharati University, Santiniketan, 731235, India \\ Correspondence should be addressed to S K Maitra; Email: dgp_skmaitra@yahoo.co.in
}

\begin{abstract}
The major objective of the present study was to demonstrate the actions of exogenous melatonin on ovaprim (synthetic GnRH and domperidone)-induced final oocyte maturation focusing on the oxidative status of pre-ovulatory follicles in the carp Catla catla. Accordingly, gravid carp during the early spawning phase of the reproductive cycle were injected with melatonin and/or ovaprim at different time intervals or luzindole (a pharmacological blocker of melatonin receptors) before their administration. We studied their effects on the latency period, the rate of germinal vesicle breakdown (GVBD; a visual marker of final oocyte maturation) in oocytes, and the levels of maturation-promoting factor (MPF), as well as oxidative stress, different antioxidants, melatonin and MT1 melatonin receptor protein in the extracts of pre-ovulatory follicles. Notably, melatonin treatment $\mathbf{2} \mathrm{h}$ before the injection of ovaprim resulted in the shortest latency period as well as the highest rate of GVBD and MPF formation. Exogenous melatonin, irrespective of the injection schedule, caused a significant reduction in intra-follicular oxidative stress and an increase in the levels of both enzymatic and nonenzymatic antioxidants, melatonin and its receptor protein. Concentrations of ovarian melatonin in each fish exhibited a significant negative correlation with the level of oxidative stress, but a positive correlation with the rate of GVBD and the activity/level of different antioxidants. However, no significant effects of melatonin and/or ovaprim were detected in luzindole-pretreated carp. Collectively, the present study provides the first evidence that melatonin pretreatment in carp ameliorates ovaprim actions on the process of final oocyte maturation by the formation of MPF and alleviates oxidative stress in pre-ovulatory follicles by stimulating different antioxidants.

Reproduction (2016) $151285-296$
\end{abstract}

\section{Introduction}

Pineal hormone melatonin ( $\mathrm{N}$-acetyl-5-methoxytryptamine) is considered as a potent candidate in the regulation of reproduction in different vertebrates including fish (Maitra et al. 2013). Circulating profiles of this hormone in an annual reproductive cycle exhibit a close relationship with the stages of oocyte development (Maitra et al. 2005) as well as the plasma levels of ovarian steroids in the carp Catla catla (Chattoraj et al. 2009a). Exogenous melatonin, when administered to this fish species at the same dose and for identical duration, but in different reproductive seasons, leads to the stimulation or inhibition of or no subtle changes in gonadal functions (Bhattacharya et al. 2007). It is generally agreed that melatonin acts primarily on the hypothalamo-pituitary-gonadal (HPG) axis to regulate seasonality of fish reproduction (Falcón et al. 2007). However, an in vitro study has demonstrated for the first time (Chattoraj et al. 2005) that melatonin may act locally on the carp ovary, as prior incubation of denuded oocytes with melatonin augments the action of maturation-inducing hormone $(\mathrm{MIH})$ or $17 \alpha, 20 \beta$-dihydroxy4-pregnen-3-one $(17 \alpha, 20 \beta$-DP) on oocyte maturation by the formation of maturation-promoting factor (MPF) - a complex of two proteins, cyclin B and cyclin-dependent kinase Cdk1 (Yamashita et al. 1992). Subsequent localization and dynamics of a $37 \mathrm{kDa}$ melatonin receptor protein in the oocytes of the same fish (Chattoraj et al. 2009b) also argue in favor of extra-hypothalamic actions of melatonin. The study on zebrafish reports that melatonin plays a critical role in promoting seasonal reproduction by activating the cascade starting from the kiss peptide, which, in turn, stimulates hypothalamic neurons to produce gonadotropin-releasing hormone $(\mathrm{GnRH})$, and by acting directly on gonads that regulate the transcription of two important genes whose proteins are involved in oocyte competence and maturation (Carnevali et al. 2011). Likewise, a study on killifish (Lombardo et al. 2012) provides evidence that endogenously synthesized or exogenously added melatonin acts on steroidogenesis by regulating steroidogenic enzyme activities in theca and granulosa cells of the ovary (Tamura et al. 2009). Moreover, the discovery that melatonin due to its lipophilic nature can easily cross the plasma membrane of cells to act directly as a scavenger of free radicals (Tan et al. 1993) followed by 
studies demonstrating the stimulation of antioxidative enzymes by melatonin (Rodriguez et al. 2004) and even scavenging actions of its metabolites on free radicals (Galano et al. 2013) added a new dimension to the current understanding on the physiological role of melatonin as a potent antioxidant (Zhang \& Zhang 2014) in the regulation of ovarian functions in at least mammals (Tamura et al. 2014).

Generation of a large amount of free radicals during oocyte maturation and ovulation is known to cause an elevated oxidative stress (Tamura et al. 2008). Melatonin detected in the pre-ovulatory follicles seems to minimize oxidative stress and ultimately to improve the quality of oocytes (Tamura et al. 2014). The information gathered from mammalian studies also reveals that melatonin acts on various cells of ovarian follicles as an indirect antioxidant to stimulate several antioxidative agents, such as superoxide dismutase (SOD), catalase (CAT), glutathione peroxidase (GPx), glutathione transferase (GST) and reduced glutathione (GSH), which metabolize free radicals to reduce oxidative stress (Reiter 1996). In the absence of comparable data from any fish study, a recent finding on carp provides the first indication that intra-ovarian melatonin might be implicated in the reduction of oxidative stress to augment ovarian functions during spawning (Hasan et al. 2014). In such study, a significant positive correlation between the concentrations of melatonin and the levels of different antioxidative agents (SOD, CAT and GST) in the ovary is noted throughout the annual reproductive cycle. Thus, it is likely that melatonin performs its regulatory functions on fish reproduction by receptor-mediated hormonal actions on the HPG axis and/or by acting as an antioxidant to reduce intra-follicular oxidative stress. However, it remains unknown whether during spawning, melatonin modulates the actions of hypothalamic $\mathrm{GnRH}$ on the oxidative status of the ovary to induce final oocyte maturation in fish.

The use of hypothalamic GnRH or its analogs has been the most successful attempt to induce maturation and spawning in fish (Mylonas \& Zohar 2001). Since dopamine inhibits basal and $\mathrm{GnRH}$-induced gonadotropin release from the pituitary (Chang \& Peter 1983), domperidone, a dopamine receptor antagonist (Peter et al. 1988), is added to $\mathrm{GnRH}$ in a commercial product 'ovaprim' (a combination of GnRH and domperidone) for ready use in fish farming (Nandeesha et al. 1990). The developmental stage of oocytes in fish is critical to the timing of $\mathrm{GnRH}$ release from the hypothalamus to stimulate maturation and ovulation (Williot et al. 2002). Thus, ovaprim treatment is effective only when the ovaries are fully developed and the fish are ready to spawn.

The present study is an attempt to demonstrate the influences of exogenous melatonin on ovaprim-induced final oocyte maturation and to elucidate the physiological mechanism of response by focusing on the role of different antioxidants in the ovarian follicles of sexually mature carp during the spawning phase of an annual cycle. Additionally, luzindole, a pharmacological blocker of melatonin receptors with high selectivity (Dubocovich 1988), is used before hormonal treatments to ascertain the role of melatonin receptors in the mechanism of ovarian response in carp.

\section{Materials and methods}

\section{Chemicals and reagents}

The melatonin antiserum (sheep anti-melatonin antibody) and tritiated melatonin ([O-methyl- $\left.{ }^{3} \mathrm{H}\right]$ melatonin, specific activity $84.0 \mathrm{Ci} / \mathrm{mmol}$ ) were purchased from Stockgrand Ltd (Surrey, UK) and GE Healthcare Life Sciences (Buckinghamshire, UK) respectively. The primary antibodies of MT1, Cdc34 and cyclin B were procured from Santa Cruz Biotechnology, while 5-bromo-4-chloro-3-indolyl-phosphate/nitro blue tetrazolium (NBT) and the secondary antibodies were supplied by Bangalore Genei (Bangalore, India). 'Ovaprim' was procured from Virbac Animal Health India Pvt. Ltd (Mumbai, India). NAD, GSH (reduced glutathione), glutathione disulfide (GSSG; oxidized glutathione), NBT and TCA were supplied by SRL (Mumbai, India). Melatonin, $\mathrm{NaN}_{3}$ (sodium azide), PMS, PMSF, TBA, EDTA, PVDF membranes, DTNB (5, 5' -dithiobis(2nitrobenzoate)), anti- $\beta$-actin (mouse monoclonal anti- $\beta$-actin IgG), CDNB (1-chloro-2,4-dinitrobenzene), and all other chemicals and reagents of the highest commercially available purity were purchased from Sigma-Aldrich Chemical Co. (St Louis, MO, USA).

\section{Collection, selection and maintenance of fish}

Adult female carp (Catla catla, Cypriniformes), weighing 1000-1200 g, were captured from large water bodies around Santiniketan (latitude $23^{\circ} 39^{\prime} \mathrm{N}$, longitude $87^{\circ} 42^{\prime} \mathrm{E}$ ) in India during the early spawning phase (June) of the annual reproductive cycle. Immediately after the capture, the fish were brought to the laboratory and then transferred to large open-air cement tanks measuring $\sim 4 \mathrm{~m}$ (length) $\times 2 \mathrm{~m}$ (width) $\times 1 \mathrm{~m}$ (depth) for acclimatization under ambient conditions (duration of natural day length: $13 \mathrm{~h} 10 \mathrm{~min}$, water temperature or WT: maximum $29.0^{\circ} \mathrm{C}$, minimum $27.5^{\circ} \mathrm{C}$ ) for about 1 week. The tanks were provided with artificial aeration and continuous flow of water. All fish had free access to prepared balanced fish food comprising $35 \%$ fish meal, $28 \%$ mustard oil cake, $28 \%$ rice bran, $2 \%$ each sunflower and cod liver oil, 5\% carboxymethyl cellulose, and multivitamin/multi-mineral tablets throughout the period of acclimatization (Bhattacharya et al. 2007). Water quality in each tank was critically monitored for maintaining hygienic conditions. Laboratory care of fish and adopted study schedules were duly approved by the 
Institutional Animal Care and Use Committee (IACUC) of the Department of Zoology, Visva-Bharati University following the guidelines of the funding agency Department of Biotechnology (BT/PR11423/AAQ/03/421/2008 dated 25 June 2009), New Delhi, Government of India.

\section{Experimental paradigms}

A total of 72 sexually mature female carp with protruded genital papilla, dilated and bulging abdomen were randomly and equally $(n=9)$ divided into eight groups for undergoing any of the following separate treatments: i) the vehicle of the hormone (control), ii) ovaprim, iii) melatonin, iv) melatonin administered with the a) primary (1st) - or b) booster (2nd) dose of ovaprim or c) $2 \mathrm{~h}$ prior to the primary dose or d) $2 \mathrm{~h}$ after the booster dose of ovaprim, v) luzindole 15 min before the injection of melatonin followed by the primary dose of ovaprim. Each of these eight experiments using nine individual fish was carried out on two consecutive days: i) on the first day, three fish were used separately for the calculation of their latency period between the last hormone injection and ovulation; ii) on the next day, the same treatment was repeated with the remaining six individuals and about 500 mature ovarian follicles from each fish were collected before 15-20 min of their calculated latency period. The fish used in different experiments were handled identically to reduce possible stress during their capture and treatments.

Following the instructions of the supplier, commercially available ovaprim ( $1 \mathrm{ml}$ containing $20 \mu \mathrm{g}$ salmon GnRH analogue or sGnRHa and $10 \mathrm{mg}$ domperidone dissolved in propylene glycol) was injected intramuscularly in two doses $(0.15 \mathrm{ml} / \mathrm{kg}$ body wt as the primary dose followed by $0.35 \mathrm{ml} / \mathrm{kg}$ body wt as the booster dose at a $2 \mathrm{~h}$ interval). Melatonin and luzindole were initially dissolved in $10 \mu \mathrm{l}$ ethanol and then diluted with teleost saline $\left(20 \mathrm{mg} \mathrm{Na} \mathrm{CO}_{3} / 100 \mathrm{ml}\right.$ of $0.6 \% \mathrm{NaCl}$ ) until the desired concentrations were obtained for intramuscular injection of melatonin at the dose of $25 \mu \mathrm{g} / 100 \mathrm{~g}$ body wt and intra-peritoneal injection of luzindole at the dose of $0.1 \mu \mathrm{g} / 100 \mathrm{~g}$ body wt. The fish used as the control for the treatment groups were intramuscularly injected with the vehicle (i.e. teleost saline: ethyl alcohol mixture 9:1 $(\mathrm{v} / \mathrm{v}))$ of the hormone/drug. The volume $(0.5 \mathrm{ml})$ of the injected solution was identical for different fish groups. On each occasion, each fish was injected with appropriate agent(s) during the late afternoon (between 1600 and $1800 \mathrm{~h}$ ) under natural photo-thermal conditions.

\section{Determination of the latency period and collection of mature follicles}

Determination of the latency period between the last hormone injection and the occurrence of ovulation in each experimental fish was initiated after $6 \mathrm{~h}$ of the treatment by applying gentle pressure on the abdomen in an anterior-to-posterior direction and repeating the same procedure every $15 \mathrm{~min}$ until mature ova could be manually removed (Springate et al. 1984). Once the latency period of respective fish group was known, the same treatment was repeated with six fresh individuals. At the end of each experiment, the fish were anesthetized with phenoxy-ethanol $(1: 20000, \mathrm{v} / \mathrm{v})$ and killed 15-20 min before their calculated latency period, or after $16 \mathrm{~h}$ of the last injection of the hormone or its vehicle (when no ovulation could be detected manually). Quick dissection was followed for the removal of ovaries and the collection of mature follicles from them.

A part of each ovary was subjected to ice-cold phosphate buffer for sudden cold shock to separate mature follicles from the adjoining ovarian tissues. About 500 large, round yolk-laden follicles with diameter $>1.0 \mathrm{~mm}$ were collected from each ovary. Out of them, about 100-150 follicles were randomly selected for the determination of the rate of germinal vesicle breakdown (GVBD) and the remaining (350-400) follicles were homogenized and sonicated at $4{ }^{\circ} \mathrm{C}$ in a homogenizing buffer $(50 \mathrm{mM}$ Tris- $\mathrm{HCl}$ buffer, $\mathrm{pH} 7.4,1 \mathrm{mM}$ EDTA, $100 \mathrm{mM}$ sucrose, $1 \mathrm{mM}$ PMSF and $1 \%$ leupeptin hemisulfate), to prepare $10 \%$ tissue homogenate, which was stored at $-80{ }^{\circ} \mathrm{C}$ until used for quantitative estimation of different biochemical components of interest.

\section{Determination of the rate of GVBD}

Isolated mature follicles from each ovary were immersed in a clearing solution (ethanol-formalin-acetic acid $6: 3: 1)$ and used for the determination of the rate of GVBD under a microscope (Olympus, BX51, Japan) with in-built photo-micrographic attachments and an image analyzing device (Chattoraj et al. 2005). Results of each observation are expressed as percentage.

\section{RIA of melatonin}

Follicular homogenates of each fish were separately centrifuged at $1500 \mathrm{~g}$ at $4{ }^{\circ} \mathrm{C}$ for $10 \mathrm{~min}$ to discard the cell debris and to use the supernatants $(500 \mu \mathrm{l}$ in duplicate) separately for extraction in chloroform $(2 \mathrm{ml})$ (Seth \& Maitra 2011). The extracted samples were resuspended in $300 \mu \mathrm{l}$ PBS-gelatin buffer $(0.2 \mathrm{~mol}$ sodium phosphate/l, $0.15 \mathrm{~mol} \mathrm{NaCl} / \mathrm{l}, 0.05 \%$ gelatin, $10 \mathrm{mmol}$ EDTA/l and $0.15 \% \mathrm{NaN}_{3} ; \mathrm{pH} 6.0$ ) and used for the estimation of melatonin concentrations following a specific well-calibrated RIA, using $\left[{ }^{3} \mathrm{H}\right]$ melatonin (specific activity $84.0 \mathrm{Ci} / \mathrm{mmol}$ ) as the tracer $(100 \mu \mathrm{l}$ equivalent to about 4000 c.p.m.) and melatonin antiserum (sheep anti-melatonin antibody) at a final dilution of 1:4000 (Hasan et al. 2014). The assay was validated by 
both parallelism and recovery tests. The sensitivity of the assay was $10 \mathrm{pg} / \mathrm{g}$ tissue. The intra- and inter-assay coefficient of variations were $<6.1$ and $<7.4 \%$ respectively.

\section{Electrophoresis and immunoblotting}

The protein content of samples, used for electrophoresis and western blot analysis, was analyzed on $12.5 \%$ Laemmli SDS-PAGE and was visualized by $0.1 \%$ Coomassie brilliant blue (overnight) followed by destaining or processed for immunoblotting on the PVDF membrane by a wet electroblotting method (Chattoraj et al. 2005, 2009b). The PVDF membranes were incubated separately with primary antibody (1:1000 dilution) raised against a peptide corresponding to an amino acid sequence at the carboxy terminus of cyclin B1 of rat origin or rabbit anti-PSTAIRE (for p34Cdk1) or primary polyclonal antibodies against MT1 followed by incubation with the respective secondary antibody (dilution 1:500). The specificity of each antibody was separately determined by pre-absorbing the antibodies with the corresponding immunizing antigen before incubation of the samples. Individual band intensity of each immunoblot was quantified by densitometry using the freely available ImageJ Software (Seth \& Maitra 2011).

\section{Malondialdehyde level as the measure of lipid peroxidation}

The supernatants of the follicular extracts were used to measure the level of Malondialdehyde (MDA) equivalents derived as a product of lipid peroxidation by thiobarbituric acid-reactive substances (TBARS) assay (Draper \& Hadley 1990) with minor modifications.

\section{Antioxidative agents}

The samples were used separately for quantitative estimations of different antioxidative agents following well-calibrated specific spectrophotometric methods. Each assay was validated by serial dilutions of the substrates and/or addition of selective inhibitors of respective enzymes (Hasan et al. 2014).

\section{Enzymatic antioxidative agents}

Superoxide dismutase

SOD activity was measured following a spectrophotometric method (Ewing \& Janero 1995) based on the assessment of $\mathrm{O}_{2}^{-}$-mediated NBT reduction by an aerobic mixture of $\mathrm{NADH}$ and PMS. The superoxide radicals were generated in $3 \mathrm{ml}$ Tris- $\mathrm{HCl}$ buffer $(16 \mathrm{mM}$, $\mathrm{pH}$ 8.0) containing $1 \mathrm{ml}$ NBT $(50 \mu \mathrm{M})$ solution and $1 \mathrm{ml}$ $\mathrm{NADH}(78 \mu \mathrm{M})$ solution, and the sample extracts were mixed. The reaction was started by adding $1 \mathrm{ml}$ PMS solution $(10 \mu \mathrm{M})$ to the mixture, and following incubation at $25^{\circ} \mathrm{C}$ for $5 \mathrm{~min}$, absorbance was measured at $560 \mathrm{~nm}$ against the reagent blank. To validate the assay, serial dilutions of $\mathrm{NADH}$ and PMS were used.

Catalase

CAT activity was measured using the method described by Aebi (1984). Absorbance was monitored at $240 \mathrm{~nm}$ up to $90 \mathrm{~s}$ at $15 \mathrm{~s}$ intervals. The assay was validated by treating the tissue homogenates with sodium azide, a known inhibitor of CAT activity (Aksoy et al. 2004).

\section{Glutathione peroxidase}

GPx activity was measured following a method (Castro et al. 2008), in which absorbance was measured at $492 \mathrm{~nm}$ against the blank (100 $\mu$ l extra OPD solution instead of sample). Serial dilutions of the substrate (o-phenylenediamine; OPD) of GPx were used to validate the assay.

\section{Glutathione S-transferase}

GST activity was spectrophotometrically assessed (Habig et al. 1974) using GSH (2.4 mM) and 1-chloro-2,4dinitrobenzene $(\mathrm{CDNB}, 1 \mathrm{mM})$ as the substrate. The assay was initiated by adding $100 \mu \mathrm{l}$ of the sample in $900 \mu \mathrm{l}$ of the assay cocktail $(980 \mu \mathrm{l}$ PBS, $\mathrm{pH} 6.5$, $100 \mathrm{mM}$ CDNB and $100 \mathrm{mM}$ GSH). Phosphate buffer saline ( $\mathrm{pH}$ 6.5) was used as a negative control and absorbance was measured at $340 \mathrm{~nm}$ at a regular interval of $60 \mathrm{~s}$ for $5 \mathrm{~min}$. The assay was validated by treating the tissue homogenates with coniferyl ferulate, a known specific inhibitor of GST activity (Chen et al. 2013).

\section{Glutathione reductase}

Glutathione reductase (GRd) activity was determined by monitoring the glutathione-dependent oxidation of $\mathrm{NADPH}$ at $340 \mathrm{~nm}$, in a reaction mixture containing $950 \mu$ of $0.15 \mathrm{mM}$ NADPH, $0.5 \mathrm{mM}$ glutathione, $3 \mathrm{mM}$ $\mathrm{MgCl}_{2}$ in $50 \mathrm{mM}$ Tris (pH 7.5) and $50 \mu$ extract (Pinto \& Bartley 1962). Corrections were made for NADPH oxidation in the absence of glutathione.

Non-enzymatic antioxidative agent: GSH (reduced glutathione)

Quantity of GSH, a faithful non-enzymatic antioxidative agent, in each follicular extract was measured following the method described by Ellman (1959). The level of GSH in each sample was calculated by extrapolating the data from the standard graph prepared using GSH.

\section{Statistical analysis}

The densitometric value of each immunoblot representing a specific protein was calculated from the means of 
intensity of different bands of the same protein. The obtained value of the band intensity of each protein (i.e. MT1, p34Cdk1 or cyclin B) was then normalized by the intensity of $\beta$-actin and expressed as relative densitometric units (a ratio of the band intensity of the protein to $\beta$-actin for each sample) (Shao et al. 2007). Mean \pm s.E.M. values of such data $(n=6)$ for respective immunoblots as well as for remaining variables were separately analyzed by one-way ANOVA. Where $F$ values indicated significance, the means were compared by a post hoc multiple range test, taking $P<0.05$ as the threshold. In addition, a correlation coefficient test was followed to search for correlation separately between the profiles of melatonin, different antioxidative agents, intracellular stress marker, relative density of MT1, cyclin B and Cdc34 proteins in the follicular extracts as well as the rate of GVBD in the ovary of each carp (any two variables at a time). We followed a linear regression analysis for expressing the dependence of a response variable on an independent (predictor) variable. In either case, the significance was considered at the $P<0.05$ level. SPSS and Graph Pad Prism 6.03 Software were used for statistical analysis and data presentation respectively.

\section{Results}

\section{Latency period}

Within the period (6-16 $\mathrm{h}$ after the last injection) of the study, no ovulation was detected in both the control and only melatonin-treated fish, while the latency period between the last injection of ovaprim and the release of eggs in the remaining fish varied between 7 and $12 \mathrm{~h}$. The latency period was longest $(11.80 \pm 0.74 \mathrm{~h})$ in the luzindole-pretreated, ovaprim-injected carp and lowest $(7.30 \pm 0.22 \mathrm{~h})$ in the fish treated with melatonin $2 \mathrm{~h}$ prior to the 1 st dose of ovaprim. Relative to the latency period in the only ovaprim-treated carp $(10.47 \pm 0.59 \mathrm{~h})$, no significant changes were found in the fish treated with melatonin with the 1 st dose, or $2 \mathrm{~h}$ after the 2 nd dose of ovaprim.

\section{Rate of GVBD}

One-way ANOVA of the data on the rate (\%) of meiotic resumption in the oocytes (GVBD) revealed significant effects of different treatments $(F=37.6, P \leq 0.01)$ as well as the schedule of treatment $(F=59.4, P \leq 0.01)$. The rate of GVBD, relative to the values $(13.0 \pm 1.3 \%)$ in the control (vehicle-injected) fish, was significantly increased $(49.0 \pm 2.7 \%)$ in carp that were treated with only ovaprim. Exogenous melatonin also led to an increased rate of GVBD, though its influences markedly varied with the schedule of its treatment relative to the injection of ovaprim in split doses. Injection of only melatonin led to $26.3 \pm 2.4 \%$ GVBD, but its co-treatment with ovaprim at the 1 st and 2 nd doses resulted in $79.3 \pm 3.8 \%$ and $69.7 \pm 2.4 \%$ GVBD respectively, while its treatment $2 \mathrm{~h}$ after the $2 \mathrm{nd}$ dose of ovaprim caused $59.3 \pm 1.8 \%$ GVBD (Fig. 1). However, the maximum rate $(96.3 \pm 3.6 \%)$ of GVBD was noted when melatonin was injected $2 \mathrm{~h}$ before the $1 \mathrm{st}$ dose of ovaprim. Notably, such influences of melatonin could not be found in the luzindole-pretreated carp.

\section{Formation of maturation promoting factor (MPF (cyclin B-Cdk1))}

In the samples that were used separately in SDS-PAGE and immunoblotting with anti-cyclin B antibody or anti-PSTAIRE (anti-Cdk1 or Cdc2) antibody, a $50 \mathrm{kDa}$ protein and a $34 \mathrm{kDa}$ protein corresponding to cyclin B and p34Cdk1 respectively were detected (Fig. 2l). One-way ANOVA of densitometric data on cyclin B immunoblots revealed a stimulatory influence of ovaprim on the formation of MPF, but the effects varied with the schedule of melatonin treatment. Melatonin injection with ovaprim at the 1 st dose resulted in $68.2 \pm 0.98$ relative expression of cyclin B protein, and at the 2 nd dose, it caused $53.4 \pm 1.63$ relative expression of cyclin B protein, while the highest $(79.6 \pm 1.74)$ value was noted in the samples of carp in which melatonin was injected $2 \mathrm{~h}$ prior to the 1 st dose of ovaprim. Notably, luzindole treatment before melatonin did not result in any stimulatory

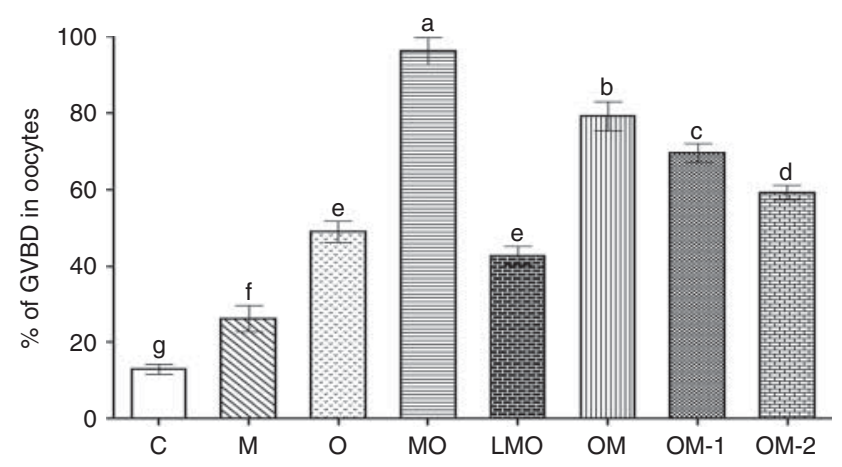

Figure 1 Histogram representation of the data on the rate (in percentage, mean \pm S.E.M. in vertical bars, $n=6$ ) of germinal vesicle breakdown (GVBD), the visual marker of oocyte maturation, in i) control (C), ii) only melatonin (M), iii) only ovaprim (O), iv) melatonin administered $2 \mathrm{~h}$ before the $1 \mathrm{st}$ dose of ovaprim (MO), v) luzindole injected $15 \mathrm{~min}$ prior to the administration of melatonin ( $2 \mathrm{~h}$ before the 1st dose of ovaprim) (LMO), vi) melatonin co-administered with 1st dose of ovaprim (OM), vii) melatonin co-administered with 2 nd dose of ovaprim (OM-1) or viii) melatonin administered $2 \mathrm{~h}$ after the $2 \mathrm{nd}$ dose of ovaprim (OM-2). In each experiment, the samples were collected 15-20 min before the calculated latency period (data shown in text) of the respective fish groups or until $16 \mathrm{~h}$ after the last injection of melatonin or its vehicle (control). The different small letters on error bar indicate significant $(P \leq 0.05)$ differences in the values of a particular variable between the different treatment groups. The same letters indicate no significant differences as determined by one-way ANOVA followed by Duncan's multiple range test. 

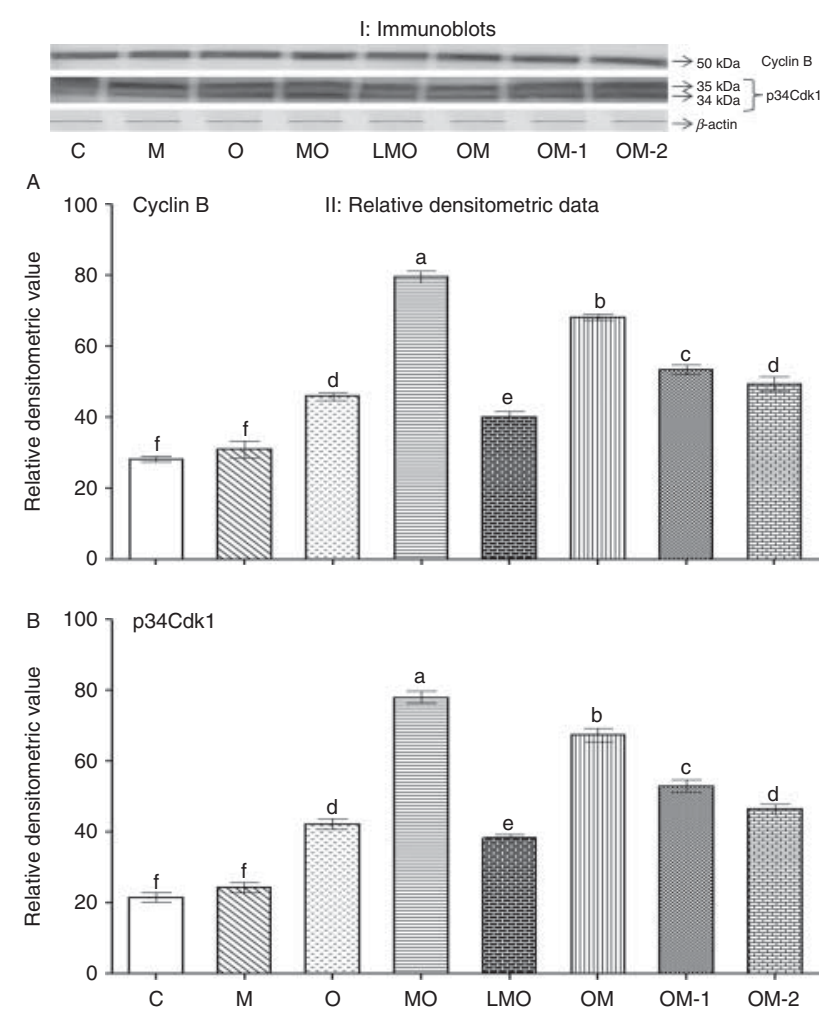

Figure 2 (I) Immunoblots of $50 \mathrm{kDa}$ cyclin B and $34 \mathrm{kDa}$ p34Cdk1 proteins detected in the ovarian homogenates of the control and different groups of the experimental carp. (II) Schematic representation of the densitometric data (mean \pm s.E.M. in vertical bars, $n=6$ ) on the immunoblots of (A) cyclin B and (B) p34Cdk1 proteins. The different small letters on error bar indicate significant $(P \leq 0.05)$ differences in the values of a particular variable between the different treatment groups. The same letters indicate no significant differences as determined by one-way ANOVA followed by Duncan's multiple range test. The abbreviations used for representing different fish groups are the same as in Fig. 1.

response in the formation of cyclin B (Fig. 2IIA). The progress of oocyte maturation was always associated with a gradual increase in the band intensity of $34 \mathrm{kDa}$ (active p34Cdk1) protein and a concomitant decrease in $35 \mathrm{kDa}$ (inactive p34Cdk1) protein (Fig. 2IIB).

\section{Intra-follicular melatonin concentrations}

Different schedules of melatonin injection, relative to ovaprim treatment in split doses, resulted in a significant $(F=54.2, \quad P \leq 0.01)$ increase in the intra-follicular melatonin concentrations over the values in the control or only ovaprim-treated carp. Maximum melatonin levels were measured in the carp to which melatonin was injected alone, or along with, or $2 \mathrm{~h}$ before the treatment of ovaprim at the 1st dose (Fig. 3A). However, luzindole treatment prior to melatonin did not result in any significant changes in the follicular melatonin titers relative to the values in the remaining melatonin-treated carp groups.

\section{Malondialdehyde}

Ovarian follicular Malondialdehyde (MDA) levels, compared with the values in control fish, were significantly $(F=46.7, P \leq 0.01)$ increased in the luzindolepretreated carp, but decreased significantly when melatonin was administered alone or along with, or $2 \mathrm{~h}$ before the treatment of ovaprim at the primary dose. However, no significant changes in MDA levels were noted between the samples collected from the remaining groups of ovaprim- and melatonin-treated fish (Fig. 3B).

\section{Enzymatic antioxidants}

Melatonin treatment resulted in a significant $(F=54.8$, $P \leq 0.01)$ increase in the activity of each measured antioxidative enzyme, such as SOD (Fig. 3C), CAT
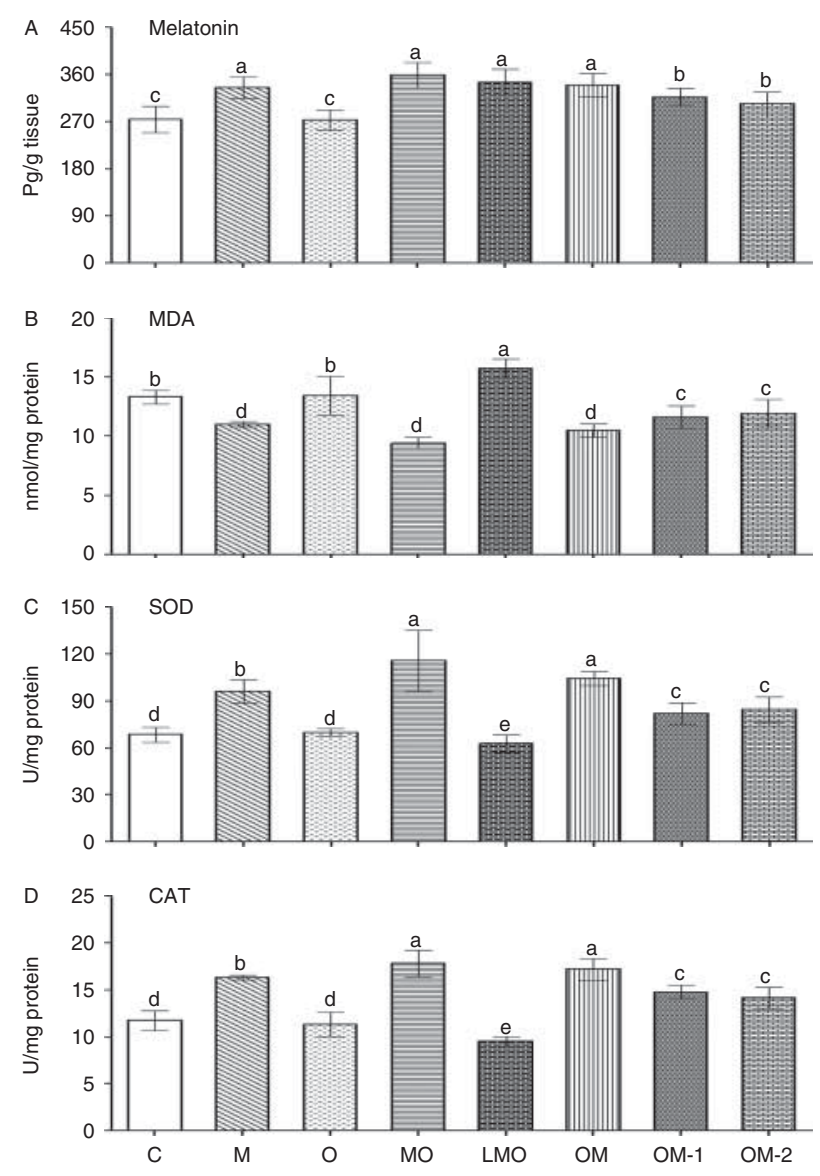

Figure 3 Schematic representation of the values (mean \pm s.E.M. in vertical bars, $n=6$ ) of intra-ovarian (A) concentrations of melatonin, (B) levels of MDA and the activity of (C) superoxide dismutase (SOD) as well as (D) catalase (CAT) following the administration of melatonin and/or ovaprim alone or in combination at different time intervals in the carp Catla catla. The different small letters on error bar indicate significant $(P \leq 0.05)$ differences in the values of a particular variable between the different treatment groups. The same letters indicate no significant differences as determined by one-way ANOVA followed by Duncan's multiple range test. The abbreviations used for representing different fish groups are the same as in Fig. 1. 

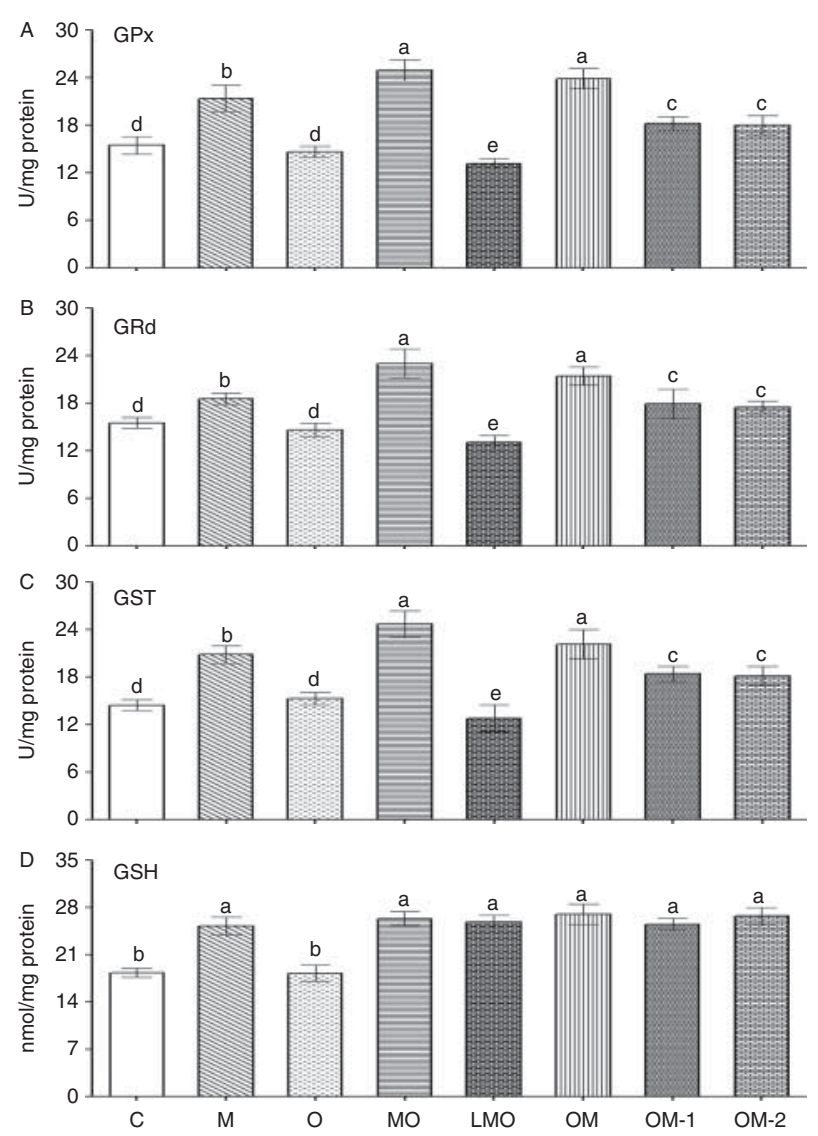

Figure 4 Histogram representation of the values (mean \pm S.E.M. in vertical bars, $n=6$ ) of different redox parameters in the carp oocyte following the administration of melatonin and/or ovaprim alone or in combination at different time intervals in the carp Catla catla.

The activity of (A) glutathione peroxidase (GPx), (B) glutathione reductase $(\mathrm{GRd})$ and $(\mathrm{C})$ glutathione s-transferase (GST) as well as the level of (D) reduced glutathione $(\mathrm{GSH})$ are plotted separately. The different small letters on error bar indicate significant $(P \leq 0.05)$ differences in the values of a particular variable between the different carp groups. The same letters indicate no significant differences as determined by one-way ANOVA followed by Duncan's multiple range test. The abbreviations used for representing different fish groups are the same as in Fig. 1.

(Fig. 3D), GPx, GRd and GST (Fig. 4A, B, and C), though significant variations were found with respect to the schedule of its injection. The activity of these enzymes was maximum when melatonin was co-administered with or $2 \mathrm{~h}$ prior to the primary dose of ovaprim. Notably, each of these enzymes showed the lowest activity in the luzindole-pretreated fish, but no significant changes between the control and only ovaprimtreated fish were observed.

\section{Non-enzymatic antioxidant: GSH (reduced glutathione)}

Intra-follicular GSH levels, relative to the values in the respective control fish, were significantly $(F=56.9$, $P \leq 0.01$ ) increased in each melatonin-treated fish group, but did not show any significant response to any dose of ovaprim. Treatment of luzindole prior to melatonin injection also did not result in any significant changes in the intra-follicular GSH content (Fig. 4D).

\section{Ovarian MT1 receptor protein}

SDS-PAGE and immunoblotting with the anti-goat polyclonal MT1 antibody detected a $37 \mathrm{kDa}$ MT1 receptor protein (Fig. 5l) in the extracts of isolated follicles. Densitometric analysis of immunoblot data revealed that the band intensity of MT1 receptor protein in the samples was always higher $(F=64.8, P \leq 0.01)$ in the fish that were treated with melatonin (alone or along with or $2 \mathrm{~h}$ before the treatment of ovaprim at the $1 \mathrm{st}$ dose) than in the respective control or 2 nd dose of ovaprim (with or without melatonin) administered or luzindole-pretreated, melatonin-injected carp (Fig. 5II).

\section{Correlation between the studied variables}

Correlation coefficient analysis revealed a significant $(P<0.05)$ positive correlation between the rate of GVBD and the activity of SOD, CAT, GPx, GRd as well as GST, but a negative correlation $(P<0.05)$ with the level of MDA. Both the intra-follicular melatonin concentration and the rate of GVBD showed a significant positive correlation with the level of GSH. The density of MT1 melatonin receptor protein in the ovarian samples also exhibited a positive correlation $(P<0.05)$ with the

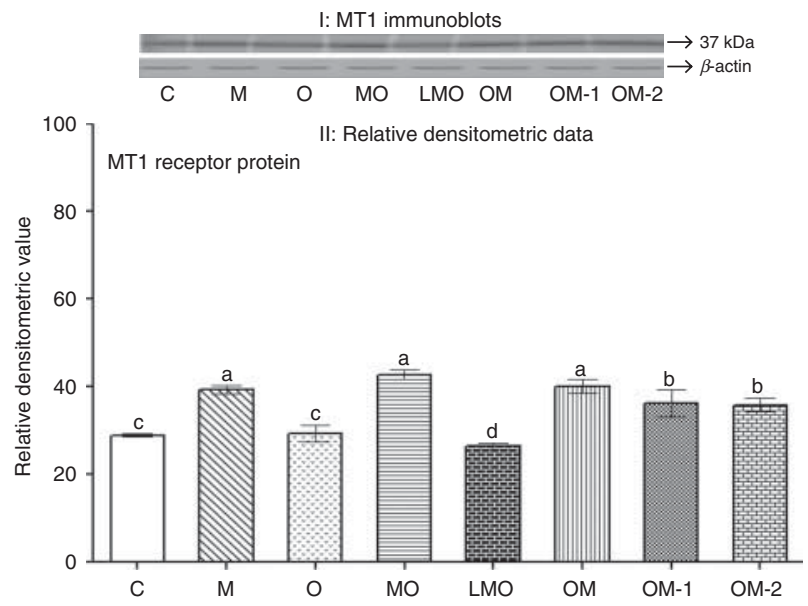

Figure 5 (I) Immunoblot of $37 \mathrm{kDa}$ MT1 receptor protein detected in the ovarian homogenates of the control and different groups of the experimental carp following the administration of melatonin and/or ovaprim alone or in combination at different time intervals.

(II) Densitometric data of the immunoblots (mean \pm s.E.M. in vertical bars, $n=6$ ) of MT1 receptor protein. The different small letters on error bar indicate significant $(P \leq 0.05)$ differences in the values of a particular variable between the different treatment groups. The same letters indicate no significant differences as determined by one-way ANOVA followed by Duncan's multiple range test. The abbreviations used for representing different fish groups are the same as in Fig. 1. 
Table 1 Results of simple correlation coefficient ( $r$ ) analysis between the values of GVBD (\%) of the oocytes and concentrations of melatonin, density of MT1 receptor protein (MT1R), cyclin B and p34Cdk1, and different redox indices in the pre-ovulatory follicles of the carp Catla catla.

\begin{tabular}{|c|c|c|c|c|c|c|c|c|c|c|c|}
\hline & \multirow{2}{*}{$\begin{array}{c}\text { Oocyte } \\
\text { maturation } \\
\text { index } \\
\text { GVBD } \\
\end{array}$} & \multicolumn{7}{|c|}{ Different redox indices in the ovary } & \multicolumn{3}{|c|}{$\begin{array}{l}\text { Relative densitometric values of } \\
\text { the intra-ovarian proteins }\end{array}$} \\
\hline & & MDA & SOD & CAT & GPx & GRd & GST & $\mathrm{GSH}$ & MT1R & Cyclin B & p34Cdk1 \\
\hline GVBD & - & $-0.528^{*}$ & $+0.611^{*}$ & $+0.465^{+}$ & $+0.516^{+}$ & $+0.440^{+}$ & $+0.586^{*}$ & $+0.427^{+}$ & $+0.616^{*}$ & $+0.971 *$ & $+0.976^{*}$ \\
\hline Melatonin & $+0.659^{*}$ & $-0.743^{*}$ & $+0.689^{*}$ & $+0.724^{*}$ & $+0.681^{*}$ & $+0.766^{*}$ & $+0.739^{*}$ & $+0.762 *$ & $+0.643^{*}$ & $+0.672^{*}$ & $+0.716^{*}$ \\
\hline MT1R & $+0.616^{*}$ & $-0.529^{*}$ & $+0.828^{*}$ & $+0.775^{*}$ & $+0.769 *$ & $+0.618^{*}$ & $+0.413^{\ddagger}$ & +0.319 & - & $+0.649^{*}$ & $+0.623^{*}$ \\
\hline Cyclin B & $+0.971 *$ & $-0.525^{*}$ & $+0.605^{*}$ & $+0.437^{+}$ & $+0.497^{+}$ & $+0.396^{\ddagger}$ & $+0.560^{*}$ & $+0.414^{\ddagger}$ & $+0.649 *$ & - & - \\
\hline p34Cdk1 & $+0.976^{*}$ & $-0.562^{*}$ & $+0.593^{*}$ & $+0.433^{+}$ & $+0.523^{*}$ & $+0.400^{\ddagger}$ & $+0.581^{*}$ & $+0.416^{\ddagger}$ & $+0.623^{*}$ & - & - \\
\hline
\end{tabular}

${ }^{*} P \leq 0.001 ;{ }^{\dagger} P \leq 0.01 ;{ }^{\ddagger} P \leq 0.05$.

activity of each antioxidative enzyme, but not with the GSH level. Notably, ovarian MDA content displayed a significant $(P<0.05)$ negative correlation with its melatonin titers, GSH levels as well as the activity of different enzymatic antioxidants. However, the density of both cyclin B and Cdc34 proteins in the follicles exhibited a significant $(P<0.05)$ positive correlation with the levels of SOD, CAT, GPx, GRd, GST and GSH (Table 1). The linear regression analysis curve between melatonin and different redox indices in the ovary as well as the values of the intra-ovarian proteins fitted with the correlation coefficient analysis data (Figs 6 and 7).

\section{Discussion}

The present study provides the first evidence that melatonin pretreatment in sexually mature carp ameliorates ovaprim actions on the ovary in reducing the latency period as well as accelerating the rate of oocyte maturation by the formation of MPF. The latency period between the last hormonal injection and the release of mature eggs reflects the egg output during the breeding operation and thereby serves as a reliable index of the best breeding performance of experimental fish (Sahoo et al. 2008). Our findings on the latency period or ovulation time in carp revealed variable influences of the administered hormones/drugs. While ovulation was found to occur within $12 \mathrm{~h}$ of ovaprim treatment, no signs of egg release were detected until $16 \mathrm{~h}$ after intramuscular injection of a single dose of melatonin, indicating that exogenous melatonin per se did not have any significant effects on the process of ovulation. Apparently, the findings on carp are not consistent with the reports on zebrafish (Carnevali et al. 2011) and killifish (Lombardo et al. 2014), where melatonin administration through water for 10 or 8 days caused an increase in the number of spawned eggs. However, it is notable that the dose, route and duration of melatonin treatment in the present and earlier studies were not identical. Thus, it may not be unwise to argue that influences of exogenous melatonin on ovarian functions are dependent on its dose, duration and/or route of administration (Falcón et al. 2010), rather than the responded fish species. Nonetheless, the seemingly most important contribution of the present study is that melatonin, when exogenously given $2 \mathrm{~h}$ prior to ovaprim, potentially increased ovaprim actions on the cascade of physiological events leading to final oocyte maturation in carp.

Only full-grown oocytes resume meiosis in response to the MIH through the formation of MPF (Yamashita et al. 1992). Using mouse anti-cyclin monoclonal and anti-PSTAIRE antibodies, we detected a $50 \mathrm{kDa}$ cyclin B protein and a conserved $34 \mathrm{kDa} 34 \mathrm{Cdk} 1$ protein in the follicular extracts of the carp. Densitometric analysis of the immunoblot data revealed a stimulatory influence of melatonin on the formation of cyclin B in the preovulatory follicles of the ovaprim-treated carp. Likewise, the study of the p34Cdk1 protein indicated an accelerated rate of conversion of a $34-\mathrm{kDa}$ protein from its inactive $35 \mathrm{kDa}$ counterpart in the follicular extracts of the same fish. These findings may serve as an indication that melatonin pretreatment accelerates the process of re-initiation of meiosis by the formation of MPF to result in the final maturation of oocytes in ovaprim-treated fish. An earlier in vitro study has also revealed that pre-incubation of carp oocytes
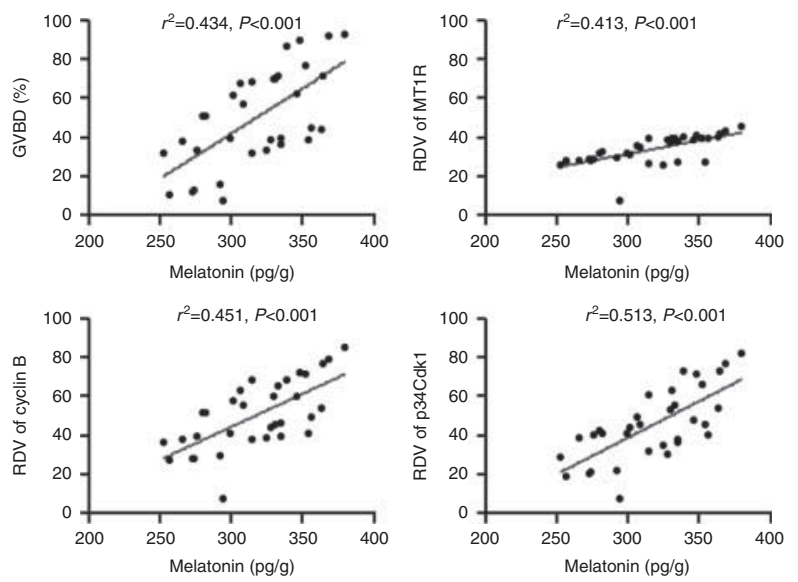

Figure 6 Scatter plots showing the single regression analysis between intra-ovarian melatonin concentrations and the rate of GVBD and the relative densitometric values of the intra-ovarian proteins in the carp ovary $(n=48)$ in an annual reproductive cycle. $r^{2}$ denotes goodnessof-fit and $P$ values indicate the significant level. 

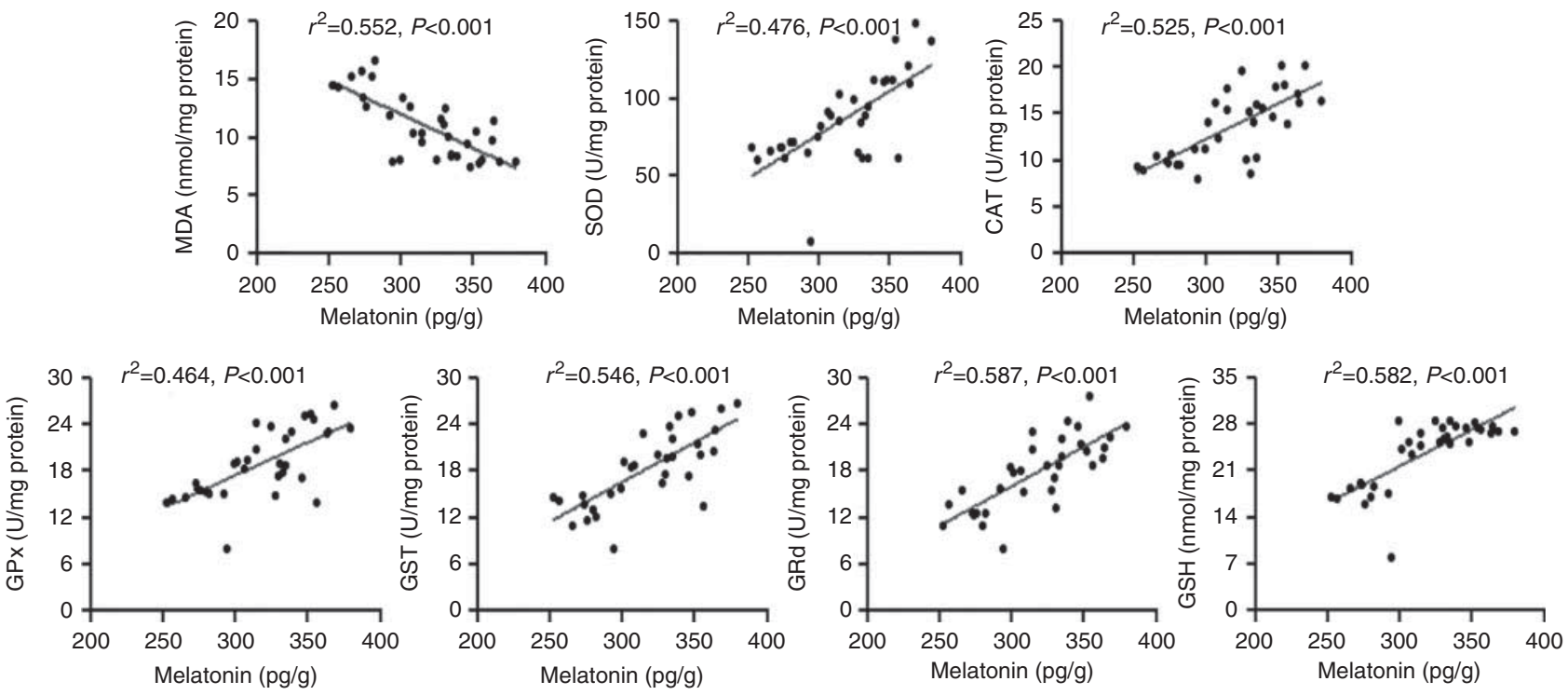

Figure 7 Scatter plots showing the single regression analysis between intra-ovarian melatonin concentrations and the activity/level of different enzymatic and non-enzymatic antioxidative agents and the stress marker in the carp ovary $(n=48)$ in an annual reproductive cycle. $r^{2}$ denotes goodness-of-fit and $P$ values indicate the significant level.

with melatonin for $4 \mathrm{~h}$ evoked the maximum GVBD response following incubation with $\mathrm{MIH}$ for $12 \mathrm{~h}$ (Chattoraj et al. 2005).

The regulatory axis of melatonin actions on fish ovary is not yet completely understood. However, the data obtained from the studies on zebrafish (Carnevali et al. 2011) and killifish (Lombardo et al. 2012) have opened up the possibility that melatonin may stimulate the release of hypothalamic GnRH. The present study by showing the stimulatory response of carp oocytes to melatonin when administered with or before ovaprim promotes an idea that the employed regimen of melatonin treatment may elicit the ovarian response by exerting major effects on the hypothalamic part of the brain, where the melatonin receptors are known to be present (Gaildrat et al. 2002). The effects of used hormones/drugs (melatonin, sGnRH and domperidone) in the brain could trigger several signaling pathways in peripheral physiological processes to result in the final maturation of oocytes. The earliest effects in carp oocytes were observed about $7 \mathrm{~h}$ after the injection of ovaprim, which need melatonin priming for $2 \mathrm{~h}$ prior to ovaprim injection. A $7 \mathrm{~h}$ latency period could be sufficient for melatonin to regulate intracellular signaling or to act via genomic actions on the ovary (Carnevali et al. 2011, Lombardo et al. 2012). Thus, the observed changes in the latency period as well as in the rate of GVBD and MPF formation in the oocytes between females treated with melatonin and ovaprim at different time intervals might be due to ovaprim actions on gonadotropic hormone $(\mathrm{GtH})$ release from the pituitary glands and the cascade of molecular events occurring thereafter in the ovary (Chattoraj et al. 2005). The likely scenario is that 2-h melatonin priming may be required for sensitizing signaling pathways for sGnRH and domperidone in the HP axis to enhance the effects of ovaprim. Thus, it is likely that ovaprim, as the substituted $\mathrm{GnRH}$, acts on the hypothalamo-hypophyseal system (Williot et al. 2002), while melatonin appears to work at both the central endocrine system and the ovary at the downstream of the reproductive axis to accelerate the process of oocyte maturation (Chattoraj et al. 2005, Lombardo et al. 2014). However, the mechanism of actions of the hormones/ drugs administered on the HPG axis, especially on the ovary, remains speculative and thereby warrants further study.

Melatonin, apart from acting as a hormone, is known to perform the functions of a free radical scavenger, electron donor and antioxidant as well (Reiter 1996). This indolamine and its metabolic derivatives by acting as a potent antioxidant may reduce intra-cellular stress (Galano et al. 2013, Zhang \& Zhang 2014). During the long period of meiotic maturation, oocytes generate and accumulate excess amounts of free radicals, chiefly reactive oxygen species, which, by inducing oxidative stress, may inhibit cell division in the oocytes (Agarwal et al. 2012). Thus, one of the major objectives of the present study was to determine the influences of melatonin on the oxidative status of pre-ovulatory follicles by measuring the levels of MDA, a reliable marker of intra-cellular stress (Parlakpinar et al. 2013), as well as the levels of different antioxidants in the same ovarian follicular extracts of the experimental carp. A high MDA level denoted an elevated oxidative stress (Yalçınkaya et al. 2013) in the pre-ovulatory follicles of the control fish. On the other hand, a significant reduction in the level of MDA and the stimulation of enzymatic (SOD, CAT, GPx, GRd and GST) as well as 
non-enzymatic (GSH) antioxidants in the follicular extracts of the melatonin-treated carp collectively demonstrated antioxidative actions of melatonin in the pre-ovulatory follicles of the concerned fish.

SODs represent a group of closely related enzymes that catalyze the breakdown of superoxide anion into oxygen and hydrogen peroxide $\left(\mathrm{H}_{2} \mathrm{O}_{2}\right.$ ) (Zelko et al. 2002). GPx and CAT then independently convert $\mathrm{H}_{2} \mathrm{O}_{2}$ to water (Gaeta et al. 2002). SOD together with GPx and CAT form the major enzyme defense mechanism against harmful free radicals. GRd catalyzes the reduction of glutathione disulfide (GSSG) to the sulfhydryl form glutathione $(\mathrm{GSH})$, which is a non-enzymatic antioxidative agent. $\mathrm{GSH}$ is a critical molecule in resisting oxidative stress and maintaining the reducing environment of the cell (Samiec et al. 1998). GST, like GPx, is an important enzyme in the glutathione redox cycle and catalyzes the conjugation of reduced glutathione via a sulfhydryl group with xenobiotic substrates for detoxification purpose (Ceballos-Picot et al. 1992). Under physiological conditions, oocytes are protected from oxidative damage by antioxidants such as SOD, CAT, GPx and GST (Angelucci et al. 2006). The present study by showing a continuous increase in the activity of both $\mathrm{GSH}$ and GSH-related antioxidant enzymes (GRd, GPx and GST) in the follicular extracts of the melatonintreated carp provides persuasive evidence of an important role of the glutathione system as the major defense against oxidative stress during the final oocyte maturation. The results of correlation coefficient analysis also depicted a significant positive correlation between the rate of GVBD, density of cyclin B as well as Cdc34 proteins, and the profiles of SOD, CAT, GPx, GRd and GST, but a negative correlation with the level of MDA in the maturing ovarian follicles. Moreover, a significant positive correlation between the concentrations of melatonin and the levels of SOD, CAT, GPx, GRd and GST in the studied ovarian follicles underlines their interplay and physiological significance in reducing oxidative stress (Hasan et al. 2014). These findings are complementary to the study on human granulosa cells, where stimulatory effects of melatonin on antioxidative enzymes have been shown to improve the quality of oocytes (Muchová et al. 1998).

Because melatonin can freely diffuse through cell membranes, the direct antioxidant effects of melatonin are unlikely to be receptor mediated. However, a melatonin receptor-based mechanism of melatonin's indirect antioxidant actions resulting from its capacity to stimulate several antioxidative enzymes cannot be completely ruled out (Zalatan et al. 2013). Therefore, the expression of melatonin receptor protein (MT1R) in the follicular extracts of the experimental carp was studied to ascertain its possible role in mediating melatonin actions on the antioxidative system in the extracts of growing follicles. Densitometric analysis of immunoblot data revealed that the band intensity of a $37 \mathrm{kDa}$ MT1R in the tissue extracts was always higher in the carp that were injected with melatonin prior to ovaprim treatment than in the respective control or only ovaprim-treated fish. Moreover, MT1R expression in the follicular extracts exhibited a positive correlation with the activity of each antioxidative enzyme and a negative correlation with the lipid peroxidation level. Such observations essentially lend support to the idea that the stimulatory influence of melatonin on final oocyte maturation in ovaprimtreated carp could be mostly due to its specific receptormediated actions on different antioxidative enzymes (Rodriguez et al. 2004). Nonetheless, additional receptor-independent melatonin actions on the nonenzymatic antioxidant may not be totally ignored, as carp ovarian GSH did not show any correlation with the profiles of MT1R but displayed a positive correlation with intra-ovarian melatonin concentrations.

The role of melatonin receptors in carrying out the effects of exogenous melatonin on oocyte maturation was examined further by the pretreatment of the experimental carp with luzindole, a competitive antagonist of melatonin receptor with high potency and selectivity (Dubocovich 1988). Remarkably, the carp that were treated with luzindole before the injection of melatonin and ovaprim thereafter did not show any ovarian response to the treatments. The latency period was longest in the luzindole-treated carp, while lowest in the fish that were treated with melatonin $2 \mathrm{~h}$ prior to the injection of ovaprim. These findings essentially suggest an important role of melatonin receptors in the mechanism of melatonin actions on ovaprim-induced final oocyte maturation in carp. However, additional data on the expression of different transcription factors, which are known to play a regulatory role in de novo synthesis of different antioxidative enzymes (Rodriguez et al. 2004), would be required to determine whether receptor-mediated actions of melatonin result in the synthesis rather than the activation of these enzymes.

In conclusion, the present study provides the first experimental data to suggest that treatment of melatonin $2 \mathrm{~h}$ before the injection of ovaprim augments the action of ovaprim to induce oocyte maturation by accelerating the rate of MPF formation, which in all probability might be related to a cascade of events leading to a reduction in oxidative stress in the growing oocytes. The results of this study also underline a critical role of melatonin receptors in oocytes in mediating stimulatory actions of melatonin on different enzymatic antioxidants. Nonetheless, considering the limitations of the present study, further study is warranted for demonstration of the mechanism of melatonin actions on the hypothalamo-hypophyseal axis, the primary target of ovaprim, in carp. Moreover, it would be important to ascertain whether melatonininduced reduction of oxidative stress is a prerequisite for the enhanced action of ovaprim on meiotic resumption of carp oocytes. 


\section{Declaration of interest}

The authors declare that there is no conflict of interest that could be perceived as prejudicing the impartiality of the research reported.

\section{Funding}

This research did not receive any specific grant from any funding agency in the public, commercial or not-for-profit sector.

\section{Acknowledgements}

The authors acknowledge the financial assistance from the Department of Biotechnology (BT/PR11423/AAQ/03/421/ 2008), New Delhi, Government of India and the award of a BSR Fellowship to KNH by the University Grants Commission (UGC), New Delhi, Government of India.

\section{References}

Aebi H 1984 Catalase in vitro. Methods in Enzymology 105 121-126. (doi:10.1016/S0076-6879(84)05016-3)

Agarwal A, Aponte-Mellado A, Premkumar BJ, Shaman A \& Gupta S 2012 The effects of oxidative stress on female reproduction: a review. Reproductive Biology and Endocrinology 10 49-80. (doi:10.1186/ 1477-7827-10-49)

Aksoy Y, Balk M, Ögüs IH \& Özer N 2004 The mechanism of inhibition of human erythrocyte catalase by azide. Turkish Journal of Biology $\mathbf{2 8}$ 65-70.

Angelucci S, Ciavardelli D, Di Giuseppe F, Eleuterio E, Sulpizio M, Tiboni GM, Giampietro F, Palumbo P \& Di Ilio C 2006 Proteome analysis of human follicular fluid. Biochimica et Biophysica Acta 1764 1775-1785. (doi:10.1016/j.bbapap.2006.09.001)

Bhattacharya S, Chattoraj A \& Maitra SK 2007 Melatonin in the regulation of annual testicular events in carp Catla catla: evidence from the studies on the effects of exogenous melatonin, continuous light and continuous darkness. Chronobiology International 24 629-650. (doi:10.1080/ 07420520701534665)

Carnevali O, Gioacchini G, Maradonna F, Olivotto I \& Migliarini B 2011 Melatonin induces follicle maturation in Danio rerio. PLoS ONE 6 e19978. (doi:10.1371/journal.pone.0019978)

Castro R, Piazzon MC, Noya M, Leiro JM \& Lamas J 2008 Isolation and molecular cloning of a fish myeloperoxidase. Molecular Immunology 45 428-437. (doi:10.1016/j.molimm.2007.05.028)

Ceballos-Picot I, Trivier JM, Nicole A, Pierre-Marie S \& Marc T 1992 Age-correlated modifications of copper-zinc superoxide dismutase and glutathione-related enzyme activities in human erythrocytes. Clinical Chemistry 38 66-70.

Chang JP \& Peter RE 1983 Effects of dopamine on gonadotropin release in female goldfish. Carassius auratus. Neuroendocrinology 36 351-357. (doi:10.1159/000123480)

Chattoraj A, Bhattacharya S, Basu D, Bhattacharya S, Bhattacharya S \& Maitra SK 2005 Melatonin accelerates maturation inducing hormone $(\mathrm{MIH})$ : induced oocyte maturation in Carps. General and Comparative Endocrinology 140 145-155. (doi:10.1016/j.ygcen.2004.10.013)

Chattoraj A, Seth M, Basu A, Srivastava TG, Porta S \& Maitra SK 2009a Temporal relationship between the circulating profiles of melatonin and ovarian steroids under natural photo-thermal conditions in an annual reproductive cycle in carp Catla catla. Biological Rhythm Research 40 347-359. (doi:10.1080/09291010802404218)

Chattoraj A, Seth M \& Maitra SK 2009 b Localization and dynamics of Mel ${ }_{1 \text { a }}$ melatonin receptor in the ovary of carp Catla catla in relation to serum melatonin levels. Comparative Biochemistry and Physiology 152 327-333. (doi:10.1016/j.cbpa.2008.11.010)
Chen C, Wu C, Lu X, Yan Z, Gao J, Zhao H \& Shaojing L 2013 Coniferyl ferulate, a strong inhibitor of glutathione S-transferase isolated from radix Angelicae sinensis, reverses multidrug resistance and downregulates P-glycoprotein. Evidence-Based Complementary and Alternative Medicine 2013639083.

Draper HH \& Hadley M 1990 Malondialdehyde determination as index of lipid peroxidation. Methods in Enzymology 186 421-431. (doi:10.1016/ 0076-6879(90)86135-I)

Dubocovich ML 1988 Luzindole (N-0774): a novel melatonin receptor antagonist. Journal of Pharmacology and Experimental Therapeutics 246 902-910.

Ellman GL 1959 Tissue sulfhydryl groups. Archives of Biochemistry and Biophysics 82 70-77. (doi:10.1016/0003-9861(59)90090-6)

Ewing JF \& Janero DR 1995 Microplate superoxide dismutase assay employing a nonenzymatic superoxide generator. Analytical Biochemistry 232 243-248. (doi:10.1006/abio.1995.0014)

Falcón J, Besseau L, Sauzet S \& Boeuf G 2007 Melatonin effects on the hypothalamo-pituitary axis in fish. Trends in Endocrinology and Metabolism 18 81-88. (doi:10.1016/j.tem.2007.01.002)

Falcón J, Migaud H, Muñoz-Cueto JA \& Carrillo M 2010 Current knowledge on the melatonin system in teleost fish. General and Comparative Endocrinology 165 469-482. (doi:10.1016/j.ygcen.2009. 04.026)

Gaeta LM, Tozzi G, Pastore A, Federici G, Bertini E \& Piemonte F 2002 Determination of superoxide dismutase and glutathione peroxidase activities in blood of healthy pediatric subjects. Clinica Chimica Acta 322 117-120. (doi:10.1016/S0009-8981(02)00163-8)

Gaildrat P, Becq F \& Falcón J 2002 First cloning and functional characterization of a melatonin receptor in fish brain: a novel one? Journal of Pineal Research 32 74-84. (doi:10.1034/j.1600-079x.2002. 1817.x)

Galano A, Tan DX \& Reiter RJ 2013 On the free radical scavenging activities of melatonin's metabolites, AFMK and AMK. Journal of Pineal Research 54 245-257. (doi:10.1111/jpi.12010)

Habig WH, Pabst MJ \& Jakoby WB 1974 Glutathione S-transferases: the first enzymatic step in mercapturic acid formation. Journal of Biological Chemistry 249 7130-7139.

Hasan KN, Moniruzzaman M \& Maitra SK 2014 Melatonin concentrations in relation to oxidative status and oocyte dynamics in the ovary during different reproductive phases of an annual cycle in carp Catla catla. Theriogenology 82 1173-1185. (doi:10.1016/j.theriogenology. 2014.08.001)

Lombardo F, Giorgini E, Gioacchini G, Maradonna F, Ferrarsi P \& Carnevali O 2012 Melatonin effects on Fundulus heteroclitus reproduction. Reproduction Fertility and Development 24 794-803. (doi:10. 1071/RD11267)

Lombardo F, Gioacchini G, Fabbrocini A, Candelma M, D'Adamo R, Giorgini E \& Carnevali O 2014 Melatonin-mediated effects on killifish reproductive axis. Comparative Biochemistry and Physiology 172 31-38. (doi:10.1016/j.cbpa.2014.02.008)

Maitra SK, Chattoraj A \& Bhattacharyya S 2005 Implication of melatonin in oocyte maturation in Indian major carp Catla catla. Fish Physiology and Biochemistry 31 201-207. (doi:10.1007/s10695-006-0025-2)

Maitra SK, Chattoraj A, Mukherjee S \& Moniruzzaman M 2013 Melatonin: a potent candidate in the regulation of fish oocyte growth and maturation. General and Comparative Endocrinology 181 215-222. (doi:10.1016/j.ygcen.2012.09.015)

Muchová J, Garaiová I, Sustrová M, Hrusková S \& Duracková Z 1998 Determination of low molecular weight antioxidant in serum of persons with Down's syndrome. Chemical Papers 52537.

Mylonas CC \& Zohar Y 2001 Endocrine regulation and artificial induction of oocyte maturation and spermiation in basses of the genus Morone. Aquaculture 202 205-220. (doi:10.1016/S0044-8486(01)00772-4)

Nandeesha MC, Rao KG, Jayanna R, Parker N, Varghese TJ, Keshavanath P, Shetty HP 1990 Induced spawning of Indian major carps through single application of ovaprim. In The Second Asian Fisheries Forum, pp 581-585. Eds R Hirano and I Hanyu. Manila, Philiphines: Asian Fisheries Society.

Parlakpinar H, Orum MH \& Sagir M 2013 Pathophysiology of myocardial ischemia reperfusion injury: A review. Medical Sciences 2 935-954. (doi:10.5455/medscience.2013.02.8082) 
Peter RE, Lin HR \& Van der Kraak G 1988 Induced ovulation and spawning of cultured freshwater fish in China: Advances in application of $\mathrm{GnRH}$ analogues and dopamine antagonists. Aquaculture 74 1-10. (doi:10. 1016/0044-8486(88)90080-4)

Pinto RE \& Bartley W 1962 The effect of age and sex on glutathione reductase and glutathione peroxidase activities and on aerobic glutathione oxidation in rat liver homogenates. Biochemical Journal 112 109-115. (doi:10.1042/bj1120109)

Reiter RJ 1996 The indoleamine melatonin as a free radical scavenger, electron donor, and antioxidant. In vitro and in vivo studies. Advances in Experimental Medicine and Biology 398 307-313.

Rodriguez C, Mayo JC, Sainz RM, Antolin I, Herrera F, Martin V \& Reiter RJ 2004 Regulation of antioxidant enzymes: a significant role for melatonin. Journal of Pineal Research 36 1-9. (doi:10.1046/j.1600-079X.2003. 00092.x)

Sahoo SK, Giri SS, Chandra S \& Mohapatro BC 2008 Evaluation of breeding performance of Asian catfish Clarias batrachus at different dose of HCG and latency period combinations. Turkish Journal of Fisheries and Aquatic Sciences 8 249-251.

Samiec PS, Drews-Botsch C, Flagg EW, Kurtz JC, Sternberg P, Reed RL \& Jones PD 1998 Glutathione in human plasma: decline in association with aging, age-related macular degeneration, and diabetes. Free Radical Biology and Medicine 24 699-704. (doi:10.1016/S0891-5849(97)00286-4)

Seth M \& Maitra SK 2011 Neural regulation of dark-induced abundance of arylalkylamine $\mathrm{N}$-acetyltransferase (AANAT) and melatonin in the carp (Catla catla) pineal: an in vitro study. Chronobiology International $\mathbf{2 8}$ 572-585. (doi:10.3109/07420528.2011.590913)

Shao R, Weijdegard B, Fernandez-Rodriguez J, Egecioglu E, Zhu C, Andersson N, Thurin-Kjellberg A, Bergh C \& Billig H 2007 Ciliated epithelial-specific and regional-specific expression and regulation of estrogen receptor $\beta 2$ in the fallopian tubes of immature rats: a possible mechanism of estrogen-mediated transport process in vivo. American Journal of Physiology Endocrinology and Metabolism 293 147-158. (doi:10.1152/ajpendo.00101.2007)

Springate JRC, Bromage NR, Elliott JRC \& Hudson DL 1984 The timing of ovulation and stripping and their effects on the rates of fertilization and survival to eying, hatch and swim-up in the rainbow trout (Salmo gairdneri R.). Aquaculture 43 313-322. (doi:10.1016/0044-8486(84)90032-2)

Tamura H, Takasaki A, Miwa I, Taniguchi K, Maekawa R, Asada H, Taketani T, Matsuoka A, Yamagata Y, Shimamura K et al. 2008 Oxidative stress impairs oocyte quality and melatonin protects oocytes from free radical damage and improves fertilization rate. Journal of Pineal Research 44 280-287. (doi:10.1111/j.1600-079X.2007.00524.x)
Tamura H, Nakamura Y, Korkmaz A, Manchester LC, Tan D-X, Sugino N \& Reiter RJ 2009 Melatonin and the ovary: physiological and pathophysiological implications. Fertility and Sterility 92 328-343. (doi:10.1016/ j.fertnstert.2008.05.016)

Tamura H, Takasaki A, Taketani T, Tanabe M, Lee L, Tamura I, Maekawa R, Aasada H, Yamagata Y \& Sugino N 2014 Melatonin and female reproduction. Journal of Obstetrics and Gynaecology Research 40 1-11. (doi:10.1111/jog.12177)

Tan DX, Chen LD, Poeggele B, Manchester LC \& Reiter RJ 1993 Melatonin: a potent, endogenous hydroxyl radical scavenger. Endocrine Journal $\mathbf{1}$ 57-60.

Williot P, Gulyas T \& Ceapa C 2002 An analogue of GnRH is effective for induction of ovulation and spermiation in farmed Siberian sturgeon, Acipenser baerii, Brandt. Aquaculture Research 33 735-737. (doi:10. 1046/j.1365-2109.2002.00711.x)

Yalçınkaya E, Cakıroğlu Y, Doğer E, Budak O, Cekmen M \& Calışkan E 2013 Effect of follicular fluid NO, MDA and GSH levels on in vitro fertilization outcomes. Journal of the Turkish German Gynecological Association 14 136-141. (doi:10.5152/jtgga.2013.53323)

Yamashita M, Fukuda S, Yoshikuni M, Bulet P, Hirai T, Yamaguchi A, Lou Y-H, Zhao Z \& Nagahama Y 1992 Purification and characterization of maturation-promoting factor in Fish. Developmental Biology 148 8-15. (doi:10.1016/0012-1606(92)90259-J)

Zalatan F, Krause JA \& Blask DE 2013 Inhibition of isoproterenol-induced lipolysis in rat inguinal adipocytes in vitro by physiological melatonin via a receptor-mediated mechanism. Endocrinology 142 3774-3782. (doi:10.1210/endo.142.9.8378)

Zelko IN, Mariani TJ \& Folz RJ 2002 Superoxide dismutase multigene family: a comparison of the CuZn-SOD (SOD1), Mn-SOD (SOD2), and EC-SOD (SOD3) gene structures, evolution, and expression. Free Radical Biology and Medicine 33 337-349. (doi:10.1016/S0891-5849(02) 00905-X)

Zhang HM \& Zhang Y 2014 Melatonin: a well-documented antioxidant with conditional pro-oxidant actions. Journal of Pineal Research $\mathbf{5 7}$ 131-146. (doi:10.1111/jpi.12162)

Received 25 August 2015

First decision 12 October 2015

Revised manuscript received 19 November 2015

Accepted 4 January 2015 